\title{
"Remédio da Ciência" e "Remédio da Alma": os usos da secreção do kambô (Phyllomedusa bicolor) nas cidades'
}

Edilene Coffaci de Lima

(UFPR)

Beatriz Caiuby Labate (UNICAMP)
Desde a metade da última década, em grandes cidades do Brasil, começou a se difundir o uso da secreção da rã arbórea Phyllomedusa bicolor, chamada de kambô. Tradicionalmente usada como revigorante e estimulante para caça por grupos indígenas do sudoeste amazônico (entre eles, Katukina, Yawanawa e Kaxinawá)², nos centros urbanos tem havido um duplo interesse pelo kambô: como um "remédio da ciência" - no qual se exaltam suas propriedades bioquímicas - e como um "remédio da alma" - onde o que mais se valoriza é sua "origem indígena". O kambô tem se difundido, sobretudo, em clínicas de terapias alternativas e no ambiente das religiões ayahuasqueiras brasileiras, isto é, entre adeptos do Santo Daime e da União do Vegetal e de suas dissidências. Os aplicadores são bastante diversos entre si: índios, seringueiros e ex-seringueiros, terapeutas holísticos, líderes ayahuasqueiros e médicos. Neste artigo apresentaremos uma breve etnografia da difusão do kambô, analisando, sobretudo, o discurso que esses diversos aplicadores têm elaborado sobre o uso da secreção ${ }^{3}$, compreendida por alguns como uma espécie de planta de poder, análoga ao peiote e à ayahuasca.

PERCURSO METODOLÓGICO: ENTRE ÍNDIOS, TERAPEUTAS E MÉDICOS

Começamos a pesquisar e acompanhar mais de perto a expansão urbana do kambô em março de 2005. Antes, em virtude de nossos trabalhos de pesquisa, já sabíamos do kambô ${ }^{4}$. A pesquisa de que trata este artigo foi iniciada recentemente e tem sido feita a partir da realização de entrevistas com aplicadores da secreção, e também com a participação, como observadoras, em palestras e eventos sobre o kambô. As entrevistas foram feitas com aplicadores de diferentes origens - dois índios, dois terapeutas amazônicos ${ }^{5}$ radicados no Acre, quatro terapeutas new age e quatro médicos - em Cruzeiro do Sul, São Paulo e Curitiba. 
Destacamos que até o momento temos nos dedicado a obter informações sistemáticas sobre a difusão urbana do kambô sobretudo entre os aplicadores, e não entre os usuários da secreção - embora tenhamos tido contato com diversas pessoas que receberam a aplicação nos centros urbanos. Esse recurso foi o possível na medida em que a introdução do uso da secreção do kambô no cardápio das terapias alternativas ainda é bastante recente, e se revelou especialmente útil ao privilegiar aqueles que estão construindo um corpus de justificações que fundamentam e legitimam o seu uso. No futuro, contudo, seria interessante ampliar as investigações para a heterogênea população que tem se interessado pela secreção do sapo verde.

\section{SAPOS: SOBRE FÁBULAS, REMÉDIOS E VENENOS}

Os sapos tiveram papel fundamental em várias culturas e épocas históricas. Argumentaremos que a expansão do uso do kambô deve ser entendida dentro deste imaginário mais amplo onde o sapo desempenha ora papel de veneno, ora de fertilidade, ora de poção mágica, ora de força diabólica, ora de remédio, ora de amuleto e assim por diante. Veremos também como o conhecimento acerca das variedades de sapos e suas utilizações permeia uma lógica de disputas e intercâmbios no campo emergente da expansão urbana do uso do kambô.

De acordo com Rudgley (1993), embora não seja possível determinar precisamente se a cultura maia clássica utilizava as propriedades psicoativas de sapos, é certo que a arte antiga dos maias incluía motivos com cogumelos, sapos e ninféias. Na Mesoamérica foram encontradas pedras, cerâmicas e esculturas com formato de cogumelos e sapos, assim como pilões decorados com motivos de sapos - cuja associação com a chuva e a agricultura é bem estabelecida, explicitando a importância do anfíbio no imaginário desta civilização.

Ainda segundo o mesmo autor, em outra obra (1999), há indícios de que os chineses também conheciam os venenos de sapos: a sua carne era considerada pelos antigos taoístas boa para a longevidade. Há, também, relatos da utilização do veneno de sapo como ingrediente na fabricação de bombas do século XVII. Na medicina vietnamita tradicional uma espécie de sapo é usada para tratar crianças com febre alta.

Os sapos desempenharam, ainda, papel importante na mitologia européia pré-histórica. Foram vinculados a diversos tipos de cogumelos, como pode ser observado através do termo inglês toadstool (literalmente "fezes de sapo", figurativamente "excremento de sapo " $^{\prime \prime}$, que se refere a cogumelos não comestíveis ou venenosos e é representado por um sapo de cócoras sobre um cogumelo (Rudgley 1999)7.

Foi freqüente a utilização dos sapos na Europa nos séculos XVI e XVII, mas existem fontes alquímicas relatando o seu uso desde o século XIII. Acreditava-se que os sapos possuíam propriedades mágicas; as suas propriedades psicoativas foram conhecidas e utilizadas por bruxas e alquimistas, inclusive como amuletos em receitas curiosas (Rudgley 1999). Ginzburg (1991) sugere que os sabás da Idade Média, com sua profusão de bruxas, lobisomens etc. implicassem o consumo de substâncias vegetais ou ungüentos, como possivelmente o centeio espigado e o cogumelo Amanita muscaria. O autor afirma que da Itália setentrional à Alemanha, à Ucrânia e à Polônia, o sapo é designado como "fada", "bruxa" ou "mago", e que, segundo várias indicações, o sapo, "como o Amanita muscaria e as anomalias deambulatórias, constituía em muitas culturas uma ligação simbólica 
com o indivisível" (1991: 264), embora não possa afirmar ao certo se isto se dá em função das propriedades psicotrópicas contidas nas secreções da sua pele.

No Brasil é famoso o muiraquitã que Macunaíma, na obra de Mário de Andrade, recebeu de sua companheira $\mathrm{Ci}$, a Mãe do Mato. $\mathrm{O}$ amuleto/tembetá de culturas amazônicas, feito de alguma pedra ou madeira esverdeada, tem costumeiramente a forma de uma rã (mas pode ter também a forma de um peixe ou tartaruga, entre outros). Há quem afirme que o muiraquitã "representa a lembrança de $\mathrm{Ci}$, ou seja, do seu Império, a floresta, ou em outras palavras a tradição - que foi roubada por um estrangeiro" (Moraes, s/d). Adiante veremos que tal interpretação da obra de Mário de Andrade não está muito distante, genericamente, do debate provocado no contexto atual da expansão do kambô para além das aldeias acreanas.

A ampla divulgação e a popularização do kambô no meio urbano fizeram surgir uma série de acusações sobre quem é ou quem são os legítimos proprietários dos conhecimentos sobre o sapo-verde. Não se pretende colocar em dúvida aqui que o conhecimento sobre o kambô originou-se entre as populações indígenas do sudoeste amazônico e espalhou-se pelo mundo, seja pelas mãos dos terapeutas amazônicos e urbanos seja pelas mãos dos cientistas. Dado tal contexto transnacionalizado, sobretudo no que diz respeito aos cientistas, uma das primeiras acusações que ocorreu - a partir dos próprios índios, mas também de indigenistas, jornalistas e vários outros profissionais que participam dos debates sobre temas socioambientais - é a de que existiu biopirataria, ou seja, recursos genéticos localizados em território brasileiro, e originários dos "índios brasileiros", foram "roubados". Embora seja necessário reconhecer que os conhecimentos indígenas sobre o kambô, com efeito, ainda não foram reconhecidos pelos cientistas dentro do atual marco legal, o que nos importa analisar aqui são as acusações que proliferam entre índios e terapeutas amazônicos e urbanos. Essas indicam, em primeiro lugar, a existência de um mercado e de uma rede de serviços inseridos num campo semântico comum.

Observamos que no discurso de diversos usuários do kambô, em contextos variados, há afirmações que são recorrentes, como a de que "existe um sapo que tem um veneno muito mais forte, que pode ser perigoso" e relatos vagos acerca de supostos acidentes ou mortes envolvendo o consumo de um "sapo indevido", ou como produto do uso indevido do kambô. Por um lado, especialmente entre os usuários urbanos, e mesmo entre estudiosos, parece haver uma confusão objetiva entre a Phyllomedusa bicolor e o Chaunus sp. (outrora Bufo $s p$.), do qual falaremos a seguir. Assim, um médico curitibano entrevistado por nós afirmou que o kambô contém bufotenina e um outro aplicador urbano do kambô, residente em São Paulo, mencionou que o kambô existe também nos Estados Unidos.

De acordo com Rudgley (1993), a espécie Chaunus marinus (outrora Bufo marinus) distribui-se por toda a América Central e América do Sul e também é encontrada nas Antilhas, na Flórida, no Havaí, na Austrália e nas Filipinas. Ela contém bufotenina ${ }^{8}$ e bufotalina, substâncias extremamente tóxicas. Outra espécie descrita por Rudgley (1999) é o Bufo alvarius, também conhecido como sapo do rio Colorado ou do deserto de Sonora e que é encontrado no México, Texas e Arizona. Este contém altas concentrações de bufotenina. Sua secreção, utilizada como um alucinógeno, pode ser lambida, sugada ou tragada em cigarros ou rapé. Há relatos de que seus efeitos são fortíssimos. Além do uso individual por experimentalistas "chupadores de sapo" a partir dos anos 60, surgiu nos Estados Unidos o culto da "Igreja do Sapo da Luz", onde o veneno do sapo é tratado como 
um sacramento (Rudgley 1999: 274-276). Jonathan Ott relata o uso do veneno fumado do Chaunus marinus (outrora Bufo marinus), o qual produziria efeitos semelhantes ao Bufo alvarius (Ott 2004).

Próximo da região que aqui nos interessa, há registro de uso do Chaunus marinus (outrora Bufo) entre os Machiguenga, que misturam os ovos deste sapo com suco de tabaco para produzir uma bebida de propriedades alucinógenas e purgativas utilizada por xamãs e rezadores. Essa infusão, segundo Shepard Jr. (2005: 197) causou uma morte entre os índios e atualmente é pouco utilizada.

Para além da confusão objetiva entre os gêneros e espécies de sapos, ou talvez justamente por conta dela, é plausível pensarmos que a referência constante por parte de vários tipos de aplicadores, e mesmo usuários, a um sapo cuja secreção é "mais forte", ou "mais perigosa", parece conferir força simbólica ao kambô e seu aplicador, seja porque é necessário ter cuidado para não se envenenar, seja porque o contato com o kambô pode representar uma espécie de iniciação, em cujo horizonte há a perspectiva futura de eventual contato com substâncias mais poderosas, misteriosas etc. Assim, o conhecimento acerca do tipo de sapo ou da sua forma correta de utilização pode funcionar como categoria acusatória com relação a outros grupos, na disputa pelo mercado emergente.

Ainda sobre as acusações no campo, notamos que entre os índios, particularmente entre os Katukina, além das acusações de "biopirataria" - termo usado indistintamente para referir-se às apropriações que cientistas e terapeutas fazem da secreção do kambô, ambas entendidas como "ilegais" -, ouve-se com freqüência a preocupação de que os aplicadores brancos poderão acabar usando o kambô de modo incorreto e "matando alguém". O receio, dizem alguns, é de que a responsabilidade disso acabará recaindo sobre eles, os conhecedores tradicionais do uso do sapo-verde. Tanto assim que em julho de 2005 ouvimos, entre os Katukina, falar que aplicadores de kambô residentes em Cruzeiro do Sul estariam usando o sapo-cururu (Bufo/Chaunus marinus) no lugar do kambô, o que seria, segundo eles, bastante perigoso.

Se alguns são acusados de usar o sapo errado, outros são criticados por mistificar a origem do sapo e da técnica de extração do veneno. Num contexto exclusivamente urbano, um terapeuta que, após conhecer Genildo (neto de Francisco Gomes, de quem falaremos adiante) ${ }^{9}$, foi até Cruzeiro do Sul para adquirir maiores conhecimentos sobre o kambô, reclamou que o conhecimento não era totalmente partilhado: "É como se fosse um tesouro, uma mina de ouro, e eles tinham receio de que outras pessoas conhecessem". Sua queixa era fundamentada principalmente no fato de que não o deixaram ver como se faz a coleta da secreção do kambô. $O$ terapeuta dava a entender que, ao ocultar a técnica da coleta, os aplicadores acreanos estariam tentando criar uma "reserva de mercado".

Entre aplicadores urbanos e amazônicos, o desentendimento acerca do preço das palhetas contendo a secreção, as porcentagens cobradas pela aplicação, a forma de transmissão dos conhecimentos, o pioneirismo na descoberta do kambô ou no estabelecimento do contato com as fontes no Acre, entre outros, são alguns dos temas recorrentes. As mútuas acusações persistem: é comum que os terapeutas tentem deslegitimar a secreção ou colocar em dúvida os conhecimentos uns dos outros. Assim, alguns aplicadores urbanos têm alegado que não garantem a origem da secreção utilizada pelos demais terapeutas. Inversamente, pode-se destacar o desenvolvimento de técnicas mais poderosas de utilização da secreção. Este é o caso de dois rapés utilizados por um aplicador do Norte (um com uma mistura de tabaco e outro com kambô puro), o qual, segundo 
ele anunciava para seus clientes daimistas, "atingia lugares do corpo que nem o Daime consegue chegar". Outra terapeuta urbana mencionou que haveria formas mais potentes de consumir a secreção do kambô, as quais seriam conhecidas apenas por alguns e não poderiam ser experimentadas por um iniciante ${ }^{10}$.

Talvez parte do fascínio contemporâneo na utilização do kambô derive do fato de se utilizar a secreção de um sapo, animal para muitos repugnante, criatura sobre a qual há uma forte carga simbólica, um imaginário que mescla, como vimos, muitas referências. Seguindo a pista da relação entre sapos e cogumelos, observamos que assim como o cogumelo do gênero Amanita tem espécies alucinógenas (Amanita muscaria e phantherina), comestíveis (Amanita caesare) e venenosas (Amanita phaloides, virosa e vera) (Carneiro 2005: 115-116), há vários gêneros e espécies de sapos com características, efeitos e usos distintos. Aplicadores e usuários navegariam numa zona nebulosa, num certo continuum entre envenenamento, alucinação, entorpecimento, estimulação e cura, o que lhes conferiria coragem e reconhecimento. Neste ponto, a utilização do kambô se aproximaria do consumo de substâncias psicoativas em geral, onde a idéia de "risco" está sempre presente, seja no tipo de substância, dosagem, forma de ingestão, contexto de uso etc ${ }^{11}$.

\section{A DIFUSÃO DO USO DO KAMBÔ}

De acordo com Lopes (2005), as primeiras aplicações de kambô em um grande centro urbano foram feitas em São Paulo, no ano de 1994. A versão agora corrente dá conta de que um único seringueiro, Francisco Gomes, falecido em 2001, que viveu entre os Katukina no riozinho da Liberdade (AC) na década de 1960, foi o principal responsável pela difusão urbana do kambô. Uma parte bastante significativa do que se tem publicado recentemente sobre o tema oficializa tal versão - confirmada pelos próprios Katukina -, que apareceu pela primeira vez em 2001 na revista Outras Palavras, editada pelo governo do Acre. Esta matéria inaugurou uma longa série de reportagens em jornais e revistas de circulação regional e nacional sobre o uso do sapo-verde - antes restrito às publicações acadêmicas. ${ }^{12} \mathrm{O}$ ápice desta divulgação jornalística do uso do sapo-verde deu-se quando o jornal New York Times, no dia 30 de maio de 2006, publicou uma matéria sobre o uso que os Katukina fazem dele. Poucos dias depois, em 13 de junho do mesmo ano, a agência de notícias Reuters também publicou uma matéria sobre o kambô - e divulgou, conjuntamente, um pequeno filme.

Dada a procura cada vez mais intensa pela utilização da secreção do sapo-verde nos centros urbanos, a Agência Nacional de Vigilância Sanitária (ANVISA) publicou no final de abril de 2004 uma portaria proibindo a propaganda do kambô, que vinha sendo feita principalmente por um domínio eletrônico registrado na internet.

Certamente as reportagens registram um fenômeno que se dá na realidade: para além das fronteiras acreanas, muitas pessoas passaram a experimentar ou a usar regularmente a secreção do sapo-verde. Através da difusão feita, sobretudo, pelos terapeutas holísticos e por adeptos e ex-adeptos dessas religiões, particularmente da União do Vegetal (UDV) e do Santo Daime, o kambô rapidamente alcançou limites até há pouco tempo imprevistos. Não é difícil encontrar hoje em São Paulo, Rio de Janeiro, Belo Horizonte, Brasília ou Curitiba quem aplique a secreção do kambô e tais cidades recebem visitas periódicas de ex-seringueiros e índios com o mesmo fim. 
Leandro Lopes (2005) traça os itinerários das viagens de Francisco Gomes, na primeira metade da década de 1990, aplicando kambô fora do Acre. Embora sem mencionar explicitamente a UDV ${ }^{13}$, o roteiro e os personagens citados no trabalho indicam que Francisco acompanhou núcleos da instituição pelo país, passando por Porto Velho (onde se localiza a origem histórica da União), Pocinhos do Rio Verde (MG), Campinas (SP) e São Paulo (SP), entre outros. Lopes também menciona que Francisco esteve em Camanducaia (MG), onde há uma igreja do Santo Daime ${ }^{14}$.

Conforme nos contou um de seus filhos, Ivanir Gomes, Francisco Gomes era um homem versado nos "saberes da floresta", conhecia muitas plantas e rezas que - mesmo depois de ter saído do seringal, estabelecendose em Cruzeiro do Sul - usava para tratar as pessoas no Alto Juruá. Para conservar seus conhecimentos, seus familiares criaram em 2002, após sua morte, a Associação Juruaense de Extrativismo e Medicina Alternativa (AJUREMA), que tem entre seus objetivos divulgar o kambô e também contribuir com pesquisas científicas que explorem seu potencial terapêutico e promovam a sua conservação ${ }^{15}$.

Fora do Acre, o kambô tem a sua divulgação garantida através de adeptos das religiões ayahuasqueiras, de neo-ayahuasqueiros (Labate 2004a) e de uma série de personagens ligados ao movimento nova era, como terapeutas holísticos e neo-xamãs. Parece haver um crescimento de terapeutas new age que se dedicam à aplicação do kambô. Parte significativa dos clientes urbanos da secreção do sapo-verde participa direta ou indiretamente destas redes.

\section{DA FLORESTA ÀS CIDADES: OS APLICADORES}

Como vimos antes, foi em 1994 que o falecido seringueiro Francisco Gomes aplicou pela primeira vez o kambô em moradores de uma grande cidade - ele estava em São Paulo. Desde então essa clientela aumentou bastante ${ }^{16}$ e, com ela, aumentou também o número de aplicadores. De uma maneira ou de outra, é possível dizer que quase todos os aplicadores de kambô em atividade atualmente relacionam-se direta ou indiretamente a Francisco Gomes. A exceção óbvia são os próprios índios com os quais ele próprio aprendeu a fazer uso da secreção (os Katukina) ou outras populações indígenas (como Kaxinawá e Yawanawá, entre outras) que fazem uso da secreção e que não tiveram contato com ele. Todos os demais aplicadores - sejam terapeutas holísticos, psicólogos ou médicos - ou aprenderam com Francisco e seus filhos e netos a fazer as aplicações ou com aplicadores que aprenderam com ele, isto é, são discípulos de seus discípulos. A seguir falaremos desses aplicadores urbanos, explicitando qual o discurso que veiculam sobre as propriedades do kambô.

A principal e mais ativa aplicadora de kambô no meio urbano, Sônia Valença de Menezes, conheceu Francisco Gomes por volta de 1999, em Camanducaia (MG). Naquela ocasião ela recebeu aplicações de kambô das mãos dele - o que, segundo afirma, teria permitido curar-se de infertilidade. Mais tarde, ela tentou contatálo no Acre para aprender a fazer as aplicações. No entanto, Francisco Gomes havia morrido. Então ela procurou por seus familiares que, a essa altura, já haviam criado a Associação Juruaense de Recursos Extrativistas e Medicina Alternativa, a AJUREMA (Leandro Lopes, comunicação pessoal, 2005). Os parentes de Francisco Gomes repassaram os conhecimentos do kambô para ela, mediante o estabelecimento de algumas condições 
- entre elas, o repasse de parte dos recursos oriundos das aplicações à AJUREMA. Aproximadamente um ano depois ou um pouco mais do que isso, a parceria de Sônia Menezes com a AJUREMA acabou sendo desfeita e ela passou a interagir diretamente com alguns Katukina, os quais, por sua vez, conheceu através dos familiares de Francisco Gomes em Cruzeiro do Sul. Passou a levar dois deles com uma certa regularidade a São Paulo e a outras cidades para participarem das sessões de aplicação de kambôn ${ }^{17}$.

Nos materiais de divulgação das aplicações de kambô de Sônia Valença de Menezes consta que a secreção do sapo-verde atua "sobre a percepção em geral, a intuição, os sonhos, a terceira visão, o inconsciente e os bloqueios que impedem o fluxo de energia vital". A mesma frase estava presente no folheto do período em que Sônia era parceira do pessoal da AJUREMA. Há um certo tempo, portanto, o vocabulário usado sugere que o kambô passa por um processo de "xamanização" no meio urbano - falamos em "xamanização" justamente porque entre os próprios indígenas (particularmente entre os Katukina) os xamãs não são mais indicados que outras pessoas para aplicarem o kambô (Lima 2005; Lima e Labate 2005 e Martins 2006). Uma tal orientação não é, contudo, homogênea, pois no mesmo material pode-se perceber um esforço de aproximação do kambô com a medicina ocidental. Assim, além de listar mais de trinta enfermidades nas quais poderia ser eficaz - como imunidade baixa, dor de cabeça, gastrite, diabetes, pressão arterial, cirrose, labirintite, epilepsia, impotência e depressão, entre outras -, no folder consta uma seção com o título "Estudo Científico", onde se afirma que "os médicos que já tomaram e pesquisaram o kambô afirmam que ele pode ser eficaz no tratamento de doenças graves $(. .$.$) , pois ele age como um grande reforçador do sistema imunológico". Mais recentemente, em fevereiro$ de 2007, circulou uma propaganda eletrônica divulgando os benefícios da aplicação do kambô na qual se afirmava que a OMS (Organização Mundial de Saúde) reconhece o uso da substância, devido a "comprovações científicas e sua grande eficiência". Tamanha ênfase nas supostas propriedades curativas do kambô, até mesmo com a suposta chancela de um órgão internacional, evidencia o processo de terapeutização atualmente em curso.

Talvez porque todos os aplicadores relacionam-se ou relacionaram-se direta ou indiretamente com o pessoal da AJUREMA (ou seja, com os familiares do seringueiro Francisco Gomes) as explicações sobre a eficácia do kambô tendem à repetição, da mesma maneira são repetitivas as informações contidas nos folhetos e outros materiais de divulgação do kambô. A AJUREMA certamente pode ser tida como um centro de difusão do uso do kambô além das aldeias, colaborando para criar uma cultura híbrida sobre o kambô, a partir da mistura de concepções de indígenas, de seringueiros, além de concepções dos meios daimistas, esotéricos e das medicinas alternativas. Tal processo certamente não está encerrado nem é fixo. De todo modo, abaixo apresentaremos algumas das concepções e práticas vigentes, privilegiando aquelas que parecem alicerçar, no meio urbano, a construção de um conhecimento partilhado sobre o kambô.

\section{PANEMA E DEPRESSÃO}

Uma das concepções em jogo, por exemplo, diz respeito à definição de "panema". No alto Juruá (e por toda a Amazônia), a panema é concebida como uma condição de má sorte na caça (Da Matta 1973). Todos os aplicadores urbanos com que conversamos mencionam o uso do kambô entre os índios como um antídoto 
anti-panema, construindo definições próprias para o termo. Assim, um aplicador urbano, João, que conhece há aproximadamente dez anos o uso do kambô, destaca seu entendimento do que vem a ser panema: trata-se de um tipo de "tristeza, negativismo, é coisa da alma, que deixa pra baixo... é depressão mesmo". O kambô vem justamente para "promover um realinhamento", para proporcionar a superação de tais condições negativas. Sônia Valença de Menezes, anteriormente citada, definiu, no I Encontro Brasileiro de Xamanismo, ocorrido em São Paulo em março de 2005, panema como "depressão de índio", termo que apareceu também na fala de Wilson, médico líder de um grupo neo-ayahuasqueiro em São Paulo ${ }^{18}$. Vale lembrar que a depressão passou, nas últimas décadas, a ser vista como um dos grandes males dos nossos tempos, passando inclusive a ser considerada pela OMS (Organização Mundial de Saúde) como a maior causa de incapacidade em países desenvolvidos (Carneiro, no prelo). O kambô representaria, portanto, uma esperança de cura num cenário de desgaste diante dos recursos da medicina ocidental.

As reelaborações em torno da utilidade do kambô não são exclusivas dos terapeutas urbanos. Nos primeiros meses de 2005, em Brasília, um filho de seringueiro, morador de Cruzeiro do Sul, destacou em conversas com um pesquisador interessado em "experimentar" a substância a estreita convivência de que haveria usufruído com os Katukina, até os nove anos de idade, entre os quais teria adquirido seus conhecimentos sobre o kambô. Sua compreensão do que vem a ser a panema não é muito diversa da que é veiculada pelos terapeutas nas grandes cidades: a panema seria, nas suas palavras, uma "má energia", um "tipo de mau olhado", e o kambô seria algo que "libera a energia ruim e repõe com energia boa".

De certa forma, talvez a fala de um índio kaxinawá que ocasionalmente aplica kambô em grandes centros urbanos ajude a clarificar melhor o processo de ampliação do que se entende por "panema" que estamos tentando aqui explicitar. Segundo esse kaxi, o kambô "nas aldeias é usado para panema [azar na caça], na cidade é para curar as doenças. Muitas pessoas vêm atrás do kampu por causa das doenças". Ele mesmo tomou kambô em São Paulo, pois, segundo disse, "estava com problema, estava com depressão. A vida na cidade é muito difícil, sentia muitas saudades da aldeia".

Em resumo, seja terapeuta urbano, amazônico ou indígena, a resposta uníssona é que o kambô ajuda a superar diversas condições negativas. De diferentes formas, os aplicadores repetiram que o kambô atua positivamente contra desequilíbrio, negativismo, mau olhado, má energia, falha na aura, baixo astral e tristeza. E seria capaz de proporcionar tantos benefícios porque vem das remotas florestas amazônicas, de lugares onde se tem pureza, harmonia e originalidade, antídotos contra os males da sociedade moderna, onde prevalece a desordem, o desequilíbrio, a poluição e o caos.

\section{DOENÇAS DO CORPO E DOENÇAS DO ESPÍRITO}

Além da definição do que se entende por panema, marca a fala de todos os aplicadores com quem conversamos uma certa oscilação entre uma interpretação new age e uma interpretação cientificista dos resultados que se podem esperar das aplicações do kambô. Assim, o mesmo terapeuta mencionado acima, João, após definir 
panema como um tipo de "negativismo", afirmou que o kambô "funciona" para alergia, dor de cabeça, enxaqueca, doenças do estômago, dores nevrálgicas, musculares, hipertensão, diabetes, doença do coração e depressão.

Um outro terapeuta, Jean, envolvido na expansão urbana do kambô mais como divulgador do que como aplicador, afirma que é preciso "vivência xamânica" para aplicar o kambô, ter "conhecimento das coisas da floresta". Pouco depois diz que o kambô "atua na corrente sangüínea, aumenta os glóbulos vermelhos e as plaquetas". Na lista de sucessos de tratamento com kambô menciona três supostos casos de cura de pessoas com câncer.

As falas são pendulares, ora inclinam-se para uma explicação espiritualista ou new age ora para uma interpretação cientificista ou médica das doenças. Justamente por serem pendulares, permitem destacar que está em jogo aqui uma definição de "cura" que é estranha à medicina ocidental. Ambas as interpretações não são mutuamente excludentes, com freqüência elas se confundem. Assim, nas palavras de João: "a cura é no espírito, é na alma. O kambô atua no plano anímico. As pessoas estão se transformando, se curando. É um remédio, talvez um dos maiores. Ele cura a dor". Estes discursos fazem parte daquilo que Luiz Eduardo Soares denominou de nova consciência religiosa, um tipo de experimentalismo cultural e religioso, um revival do interesse intelectual, político e existencial pelas "terapias, disciplinas esotéricas ou práticas alternativas" por camadas médias intelectualizadas das grandes metrópoles urbanas (1994: 122).

\section{TRATAMENTO COM KAMBÔ}

Há claramente uma tendência urbana a conceber o kambô como um "tratamento" e existem recomendações sobre o número e o intervalo das aplicações: em geral se fala de três aplicações com intervalos variados. $\mathrm{Na}$ comunidade daimista Céu da Mantiqueira, em Camanducaia (MG), é recomendado, pelos aplicadores de Cruzeiro do Sul (AC) que visitam o local, que o kambô seja aplicado uma vez por mês durante três meses consecutivos (Rose 2005: 99).

Há controvérsias, entre os aplicadores, sobre a necessidade das três aplicações. De acordo com Davi de Paula Nunes, filho de seringueiro e atualmente morador do Crôa - localidade distante aproximadamente 30 quilômetros da TI do rio Campinas, no Acre, e onde funciona o projeto Saúde Nova Vida, que inclui o kambô entre seus "remédios" -, o número de aplicações varia de acordo com o paciente e o problema. Por sua vez, o médico da UDV Glacus de Souza Brito, que conheceu Francisco Gomes na segunda metade de 1990 e que participou diretamente da expansão do kambô, disse que Francisco não tinha qualquer orientação sobre tomar em três vezes consecutivas.

Independentemente da recomendação de se fazer um esquema tríplice de aplicação, parece haver unanimidade de que o número de "pontos" feito pelos índios katukina19 - que pode chegar a mais de uma centena de uma só vez - não é adequado aos usuários urbanos. Segundo João, “uma coisa é aplicar para índio, outra coisa é para o urbano. $O$ urbano não agüentaria tantos pontos, não tem cabeça de índio. $O$ índio não tem tanta ocupação na cabeça, consegue se concentrar melhor. Quanto mais centrada a pessoa, mais harmonioso 
é o efeito". As diferenças entre índios e não-índios se devem aos seus diferentes modos de vida e talvez à sua própria "natureza". Estamos aqui diante da concepção de que os índios, moradores das florestas, são mais fortes e resistentes, além de mais equilibrados e capazes de interagirem com a natureza e com suas potências.

\section{INDIANIZACÃO DOS TERAPEUTAS E BRANQUEAMENTO DO KAMBÔ}

O reconhecimento do Kambô como um "saber indígena" é unanimidade entre os aplicadores e parece estimular entre eles um desejo de aproximação com os índios. É como se estivesse em curso um processo de indianização dos brancos: alguns aplicadores acabam identificando-se como "índios" e eventualmente se apresentando como tal. Parece tratar-se de um processo metonímico a partir do qual o contato com o kambô (parte da cultura indígena) torna o sujeito índio (todo). Assim, um ex-seringueiro do alto Juruá afirmou:

“Nós já temos um convívio intenso com os cariús [brancos]. Algumas pessoas dizem que sou índio naturalizado branco, mas eu ainda tenho uma ligação muito forte com os índios. Ainda tenho sangue, cultura... Fui criado na aldeia. Depois dos nove anos de idade a gente foi morar a dois quilômetros da cidade. Naquela época os índios daquela região eram bem disseminados (...) Até os 12 anos eu falava a linguagem indígena. Quando entrei na escola os meus colegas ficavam gozando de mim (...) eu falava tupi".

Há uma terapeuta que afirma conhecer "tudo de índio". Em suas próprias palavras, "eu estou dentro da aldeia, conheço tudo, já sou meio índio...". Ao longo do processo de intensificação do uso do kambô nas grandes cidades, seu Francisquinho, morador do Crôa, acabou reconhecendo-se como índio. Conforme consta de um material de divulgação distribuído eletronicamente, seu Francisquinho seria "neto de índios amazônicos Punhanawas"20.

Inversamente, pode-se dizer que o kambô passa por um processo de branqueamento ao ser incorporado ao cardápio de terapias alternativas fornecidas nas metrópoles. Assim, Rogério ${ }^{21}$, um médico aplicador de kambô que, segundo informou, esteve entre os Katukina e em Cruzeiro do Sul, afirmou que o uso indígena da substância é "muito cru" e que é preciso maior "sutileza". Por sutileza entende-se aqui um número menor de aplicações. Para ele, este uso "exagerado" causaria a "peia do kambô", isto é, os vômitos e mal-estar, que não seriam necessários²2. Rogério, assim como alguns outros terapeutas, tem combinado o kambô com outras terapias disponíveis em seus consultórios. Ele aplica o kambô em pontos de meridianos ${ }^{23}$ e usa o kambô ao mesmo tempo com um "sincronizador de ondas cerebrais", ferrões de abelhas, fitoterapia, acupuntura e medicina ortomolecular.

Um outro terapeuta, acupunturista de origem japonesa, orientou um índio Kaxinawá a aliar as aplicações do kambô à moxabustão - nesse caso o objetivo era tentar deixar uma cicatriz menor ${ }^{24}$. O Instituto Espiritual Xamânico, liderado pelo xamã Gideon dos Lakotas, anuncia eletronicamente que promove "a aplicação de kambô por apenas $\mathrm{R} \$ 30,00$, num pacote fechado que inclui curso de abertura de chacra coronário por apenas $\mathrm{R} \$ 20,00$, somando um total de $\mathrm{R} \$ 50,00^{\prime 25}$. Na Santa Casa, espécie de hospital da sede central da vertente daimista Cefluris, no Céu do Mapiá (AM), o kambô tem sido utilizado ao lado de terapias alternativas e esotéricas.

A fala de Rogério dá bem a idéia do que estamos chamando aqui de "branqueamento" do uso do kambô: "não precisa mais daquela aplicação hard, uma mais light dá conta; o índio não sabe tudo, alguém com conhecimentos médicos, de preferência um médico, mas com espiritualidade avançada, é melhor para o contexto 
urbano". O índio "não sabe tudo", mas sabe bastante. A questão agora seria encontrar a forma mais adequada de uso do kambô para atender à clientela nas cidades.

A recriação das formas de aplicação conhecidas, principalmente a partir do uso feito pelos Katukina e pelo pessoal da AJUREMA, é contínua. Entre os Katukina, por exemplo, as mulheres e os homens velhos aplicam kambô na perna, na panturrilha; e os homens jovens costumam aplicar no peito e nos braços. Entre os usuários urbanos a localização das aplicações não se orienta necessariamente por esse regime e há quem diga que a localização das aplicações não interfere em nada nos resultados. Outros, na dúvida, preferem reproduzir o modelo aprendido.

Ao mesmo tempo, contudo, para vários aplicadores, é importante fazer exatamente o que dizem os caboclos ou índios, mesmo que isto não Ihes pareça fazer sentido ou que eles não compreendam exatamente suas motivações. Assim, encontramos empiricamente boa diversidade com relação às orientações para a aplicação da secreção: horário, presença de jejum ou de ingestão de grandes quantidades de líquidos, restrições para aplicações em determinadas pessoas e assim por diante. Aqui voltamos ao tema abordado acima, onde se valoriza o conhecimento indígena e/ou caboclo acerca do sapo-verde. Pelo menos, o estabelecimento de laços com a "origem acreana" do kambô parece ser de importância universal. Enquanto conversávamos com Rodrigo, ele fez questão de dizer que teve contato pessoal com o kambô: diferentemente de outros, ele teria feito a coleta da secreção. Todos os aplicadores que conhecemos enfatizam que foram ao Acre, que conheceram a origem cultural e ecológica do kambô ${ }^{26}$.

Enfim, parece haver um duplo movimento, onde se valorizam os conhecimentos "tradicionais" - ora identificados com os índios, ora identificados com a categoria genérica "médico da floresta", referente geralmente a pessoas de origem cabocla, da região Norte do país -, mas também se busca superá-los. Alguns procuram se "indianizar" ou se "acaboclar"; índios podem querer se modernizar. Ao mesmo tempo que Rogério destaca a "pureza" e a "força" das florestas do Alto Juruá, recorre com freqüência a metáforas computacionais para falar sobre os efeitos que o kambô produz nos corpos. Em suas palavras, o kambô "reformata o disco... reinstala o software. (...) O kambô é como a desfragmentação do disco do computador, ele escaneia o sistema linfático". E continua dizendo que o kambô é para "imunidade biológica" e para a "imunidade espiritual". Ao final, conclui com uma outra expressão forte, dizendo que "o kambô é como um 'exorcismo biológico'", que permite agrupar, numa mesma formulação, a idéia de uma magia (demônio, espírito, religião) com a medicina (remédio, corpo, biologia).

\section{DE PANACÉIA A PLACEBO}

Os vários terapeutas com os quais conversamos revelavam um indisfarçável entusiasmo com o kambô e com as potencialidades de cura que a secreção pode oferecer. Todos igualmente pareciam saber, ainda que sem maiores detalhes, dos estudos científicos sobre as propriedades bioquímicas do sapo-verde e destacavam que o interesse de pesquisadores locais e estrangeiros pelo kambô só vem confirmar o que eles próprios estavam 
verificando há algum tempo, ou seja, a eficácia de seu uso.

É preciso enfatizar, contudo, que algumas pessoas que estiveram envolvidas na expansão urbana do kambô, como aplicadores ou divulgadores, não têm o mesmo entusiasmo com a aplicação. Pelo menos uma dessas pessoas invocou idéias e concepções do universo nova era e do universo daimista - como as idéias de "força" e "sutileza" -, ao contrário dos demais, para contradizer a eficácia do kambô no meio urbano. Assim, um médico de Curitiba, Alexandre ${ }^{27}$, com forte influência do referencial nova era em suas práticas, experimentou usar o kambô como tratamento em pacientes com câncer, aids e doenças auto-imunes (citou esclerose lateral amiotrófica, esclerose múltipla e lúpus erimatoso sistêmico). Após um certo tempo, reviu essa alternativa e excluiu o kambô do leque de terapias oferecidas em sua clínica. Segundo explicou-nos, pelo menos três motivos justificaram o abandono do uso do kambô como uma terapia: os "efeitos colaterais" (vômitos, tremores e taquicardia) da aplicação seriam excessivos para pacientes em condições já desfavoráveis. Os resultados seriam limitados, sobretudo se comparados com outras terapias utilizadas em sua clínica (citou fitoterapia, terapias oxidativas, terapia hormonal e homeopatia). Por fim, e de forma mais importante, o médico frisou que acredita que a "força" do kambô se perde no caminho entre a floresta e as cidades. Em suas palavras:

“Quando se tira a terapia do contexto, ela perde a força. No meio indígena deve ter uma força diferente. Deve ter mais coisas, as orações, a pajelança... Pegar o método isolado e colocar no meio urbano é pouco, faz perder a força.... É como comprar maconha de traficante. O kambô ficou comercial no meio urbano, ficou ainda mais descolado do contexto. Fica faltando o 'interesse forte pela cura' da parte de quem está aplicando. Isso é uma coisa sutil, mas deve ocorrer. O aplicador é fundamental. Ele tem que estar ligado com a ancestralidade, senão fica uma coisa só bioquímica. $\mathrm{O}$ elemental não está presente. Só pelo efeito químico e bioquímico é pobre" (itálicos nossos).

A idéia de que deve existir uma certa "sutileza" aparece novamente, mas com outro sentido: a sutileza aqui parece abranger um sistema cosmológico todo, e deve ocorrer, suspeita Alexandre, apenas quando as aplicações são feitas sem interesses comerciais.

Ainda que pela negativa, a fala do médico curitibano explicita que o kambô aparece como um "remédio da ciência" e como um "remédio da alma". Um não existe sem o outro e, de uma certa forma, de sua própria perspectiva, a comercialização enfraquece a face "remédio da alma" e como um "remédio da ciência" ele não oferece nenhum resultado "estrondoso". Para destacar justamente a ausência de resultados mais significativos, ele mencionou que Francisco Gomes, o seringueiro que deu início à expansão do kambô no meio urbano, morreu, em 2001, por complicações provocadas por um câncer. Tivesse a taxa de sucesso que se espera e se divulga dele, o kambô teria livrado o velho seringueiro da doença que o vitimou ${ }^{28}$.

A mesma cautela com o poder curativo do kambô, embora sustentada por argumentos diferentes, está presente na fala de um outro médico, Wilson, morador de São Paulo:

“O kambô é muito forte. A pessoa pode ter um pico glicêmico, pode ser hipertensivo, ter reações fortes... poder ser perigoso aplicar o kambô. Acho arriscado, para qualquer um... até para o Shimbam (como Francisco Gomes foi nomeado pelos Katukina), para os índios... embora eles estejam mais acostumados, faz parte da cultura deles. Precisamos promover estudos clínicos para pesquisar os efeitos terapêuticos/colateriais com todo rigor da pesquisa, com duplo cego etc".

A cautela repete-se ainda na fala do médico Glacus de Souza Brito, que disse à jornalista da revista Época, 
que "não dá para saber como pessoas com problemas cardiológicos e neurológicos seriam afetadas. Não há relatos de morte, mas tenho muitas reservas à urbanização do procedimento sem o acompanhamento da experiência indígena" (Aranha 2006). Em entrevista, Glacus Brito disse-nos que acompanhou muitas aplicações de kambô, mas após longo tempo não chegou a "nenhuma conclusão" sobre sua eficácia: "não sei dizer se cura ou não".

Não deve ser coincidência que os três depoimentos mais cautelosos - ou menos entusiasmados - que ouvimos sobre o uso terapêutico do kambô tenham sido feitos exatamente por médicos. Em uma certa medida, sempre se insinuava uma oposição entre médicos e terapeutas urbanos - explicitada na fala de um deles que sugeriu, por exemplo, que se fizessem testes duplo cego para testar a eficácia do kambô. Uma certa concepção hegemônica da medicina parecia querer se revelar, ou prevalecer, mas, ao mesmo tempo, ocultava-se, pois todos eles, de diferentes formas, sofreram influências do referencial Nova Era, ou lançam mão, em seus consultórios, de práticas médicas mais alternativas, como é o caso de Alexandre e Wilson. Uma vez mais, o kambô caminha em meio a dubiedades, ambigüidades e tensões.

\section{CONSIDERAÇÕES FINAIS}

Em abril de 2006, os Katukina da TI do rio Campinas, através de sua associação, a Associação Katukina do Campinas (AKAC), divulgaram um documento desautorizando índios de suas aldeias a colaborarem com os terapeutas urbanos e desautorizando também os terapeutas urbanos a usarem a imagem e o nome dos Katukina e da AKAC (Ofício Circular 001/AKAC, de 06 de abril de 2006). É de se destacar que a sua publicação é resultado de um intenso processo de disputas internas, pois alguns Katukina vinham, há tempos, manifestando seu descontentamento com a parceria que outros haviam estabelecido com alguns terapeutas urbanos. $O$ documento foi resultado também da pressão de alguns outros grupos indígenas detentores dos conhecimentos sobre o kambô, no contexto de uma reunião do governo sobre o "Projeto Kampô"29, em fevereiro de 2006, em Rio Branco.

Alguns terapeutas tomaram conhecimento do documento, mas não manifestaram opiniões públicas. Um deles, que não possui vínculos com os katukina, externou para nós a opinião de que "isto tem cara de coisa de branco", isto é, o documento teria sido provavelmente redigido por brancos e não pelos Katukina - infantilizando, de certa maneira, os índios ${ }^{30}$. Uma outra, que trabalha (ou trabalhava) com os katukina, mas não aceitou dar entrevista, afirmou que a carta era "de fachada", uma estratégia dos índios, cujas razões (misteriosas) não seriam facilmente compreensíveis pelos brancos ${ }^{31}$. O binômio é invertido, mas em ambos casos insinua-se a mesma recusa em aceitar a autodeterminação dos Katukina.

Uma outra terapeuta, próxima de alguns katukina, e que também não aceitou dar entrevista, disse que o documento era parte de um "balanço natural" em função do "grande interesse e cobiça" que o kambô teria despertado, e que provavelmente outros arranjos se dariam em breve, nos quais apenas os "aplicadores que são de dentro da história" (como ela mesma) teriam espaço. Outro aplicador, da região Norte, elogiou a decisão dos Katukina e enfatizou que essa era produto do mau uso que alguns estavam fazendo do kambô.

A reação dos vários aplicadores urbanos ao documento replica a lógica de disputas que observamos 
até aqui, onde há uma ligação mutante e dinâmica entre aplicadores de origens diversas, além de expressar pontos de vistas variados sobre os "autênticos" detentores dos conhecimentos sobre o kambô - que oscilam num continuum de sábios pajés a índios pouco sofisticados. Fica evidente que há uma disputa pelo mercado de uso do kambô, na qual documentos, fragmentos de discursos de antropólogos, de biólogos, de jornalistas e de índios são rapidamente incorporados como fonte de auto-legitimação, acusação e produção de novos significados. Até aqui os terapeutas amazônicos e urbanos têm sido rápidos na criação de suas próprias "cosmologias" sobre o kambô.

Até onde conseguimos apurar, o documento da AKAC foi insuficiente para conter a expansão urbana do kambô e a continuidade das parcerias entre alguns índios e terapeutas urbanos. Seja como for, é importante considerar que nos primeiros anos da difusão urbana do kambô os vários grupos indígenas conhecedores do uso tradicional da secreção não estiveram presentes, sua participação foi posterior. Em meados da década de 1990, ou mesmo antes, quando aprendia a servir-se dos conhecimentos e práticas indígenas, Francisco Gomes certamente não poderia prever os caminhos que o kambô tomaria, nem imaginaria que formaria tantos discípulos, familiares seus ou não. 


\section{NOTAS}

1 Este artigo é uma versão ligeiramente modificada de uma comunicação apresentada, em 2006, na XXV Reunião Brasileira de Antropologia, no GT "Antropologia do Corpo e da Saúde", coordenado pelas professoras Cynthia A. Sarti e Jane A. Russo.

2 Sobre a aplicação do kambô entre as populações indígenas acreanas, ver Souza et alii (2002). Para mais informações sobre o uso entre os Katukina, ver Lima (2000 e 2005).

3 Antes de continuar, cabe fazer uma breve descrição da aplicação da secreção do kambô: a aplicação é feita queimando superficialmente a pele com um instrumento pontiagudo (cipó titica, entre os índios) e, em seguida, depositando na queimadura (chamada de "ponto") a secreção do kambô - parcialmente diluída em água para desfazer a cristalização. O número de "pontos", como mostraremos adiante, varia bastante entre os usuários.

4 Edilene Coffaci de Lima há mais de quinze anos conhece os Katukina e seu uso da secreção do sapo-verde; Beatriz Labate tem acompanhado com maior ou menor distância a introdução do uso da secreção nas religiões ayahuasqueiras há cerca de dez anos.

5 Com "terapeutas amazônicos" fazemos referência aos diversos aplicadores, não-índios, de kambô, radicados no Acre, geralmente na região de Cruzeiro do Sul, e que viajam o Brasil promovendo aplicações. A expressão "terapeutas amazônicos" - que, vale destacar, não é uma categoria nativa -, tem um sentido apenas geográfico, para diferenciá-los dos terapeutas urbanos, radicados nas regiões sul e sudeste do Brasil. Embora seja provável que existam diferenças de concepção sobre o kambô entre eles, não nos dedicamos ainda em profundidade a essa investigação e, por isso, não trataremos disso aqui.

6 Carneiro (2005: 154) dá as traduções "tamborete de sapo" ou "fezes de sapo".

7 Ver também Ginzburg (1991: 263) para uma lista de palavras que indicam a relação entre cogumelos e sapos em diversos idiomas.

8 Segundo Carneiro (2005: 154), a bufotenina (5-Me-ODMT) é uma substância com propriedades alucinógenas, semelhante ao DMT, contida em algumas plantas, como a Anadenanthera peregrina, e no sapo Bufo alvarius. Também foi identificada bufotenina agindo como transmissor no cérebro de mamíferos (idem). De acordo com Rudgley (1999), a substância é cinco vezes mais potente do que o DMT e é proibida nos Estados Unidos.

9 Segundo Lopes (2005:30 e 32), Genildo recebeu todos seus conhecimentos sobre o kambô diretamente de Francisco Gomes e podia, com apenas dezenove anos, ser tido como seu sucessor direto. No final de junho de 2007, Genildo sofreu um acidente de moto em Cruzeiro do Sul e morreu prematuramente.

10 Formas aspiradas e ingeridas da secreção do kambô foram antes registradas entre os próprios Katukina (Lima 2005) e entre os Yawanawa (Perez Gil 1999).

11 Para uma discussão sobre a categoria "risco" no discurso médico sobre as substâncias psicoativas, ver Fiore (2004).

12 Para uma cronologia de todas as reportagens em revistas, jornais e TV sobre o tema ver Lima (2005) e Lima e Labate (no prelo).

13 A estreita vinculação de Francisco Gomes com a UDV tornar-se-ia mais clara após sua morte, quando foi inaugurado em Cruzeiro do Sul um núcleo que leva o seu nome: Núcleo Mestre Francisco Gomes.

14 Em Camanducaia tem-se feito uso regular da secreção do kambô. Em 2004, Isabel Santana de Rose (2005) registrou a presença de dois visitantes originários de Cruzeiro do Sul (AC), possivelmente familiares de Francisco Gomes, que aplicavam kambô, após os trabalhos de cura, em freqüentadores do Céu da Mantiqueira. Em 2006, constatamos pessoalmente a aplicação de kambô nos membros da comunidade por uma jovem liderança do Juruá, fardado do Santo Daime.

15 Tal preocupação cientificista que aparece na AJUREMA pode ser influência da origem udevista da família Gomes. Como é de conhecimento público, inclusive divulgado em seu sítio eletrônico, a UDV tem como preocupação a promoção de estudos científicos destinados a investigar os efeitos do consumo da ayahuasca. Para tanto, criou, em 1986, o Departamento Médico-Científico, o DEMEC-UDV. Seja como for, observaremos que a preocupação de validação científica dos potenciais terapêuticos do kambô é comum em diversos contextos onde ele é aplicado. 
16 Certamente os fóruns virtuais de debate (como o orkut) não são uma fonte totalmente segura de informação. De todo modo, é significativo que existam dois fóruns para tratar do kambô no orkut: um deles chamado apenas Kambô e o outro chamado Kambô Milagre Indígena, em que os participantes trocam informações (efeitos das aplicações, indicações, locais de aplicação, entre outras) sobre o uso da secreção do sapo-verde. Em 13 de março de 2007 o Kambô totalizava 459 participantes e o Kambô Milagre Indígena somava 602 .

17 Maiores detalhes sobre a parceria de Sônia Valença de Menezes com dois aplicadores katukina podem ser encontrados em Lima e Labate (2006 e no prelo) e Martins (2006).

18 A própria idéia de que o kambô serve para a caça é investida de significados próprios. Nas palavras de Jean, psicólogo que organiza sessões para um "médico da floresta" do Acre: "a caça vem até a pessoa, talvez pela irradiação do kambô, talvez pela paz que traz, fator de harmonização com a floresta, você se torna parte dela, por isto a caça se aproxima".

19 Sobre o número de aplicações feitas pelos Katukina e outros grupos indígenas, ver Lima (2005) e Lima \& Labate (no prelo).

20 Nesse caso, deve-se lembrar que vários grupos no Acre estão atualmente reivindicando o reconhecimento de sua identidade indígena, como é o caso dos Nawa, dos Apolima-Arara e dos Kontanawa. Não tencionamos excluir a possibilidade de tratar-se de mais um caso do mesmo tipo.

21 Este é um pseudônimo, pois ele pediu para não ser identificado.

22 É possível estabelecer aqui uma analogia entre as transformações das concepções acerca do vômito no contexto dos usos indígenas e mestiços da ayahuasca, e no das religiões ayahuasqueiras brasileiras, onde o último tende a ser moralizado, revestido de caráter cristão redentor (Labate 2004a).

23 Resumidamente, segundo a medicina chinesa, os pontos dos meridianos são canais presentes em nosso corpo, pelos quais circula a energia vital.

24 Vários aplicadores urbanos relataram que seus pacientes reclamam das cicatrizes deixadas pela aplicação do kambô. Não é possível deixar de destacar que, nesse caso, trata-se de uma diferença bastante forte do uso que fazem os índios, que costumam se orgulhar de terem as marcas das aplicações em seus corpos, sinais indeléveis de disposição, coragem, força e masculinidade.

25 Em: http://www.ceunossasenhoradaconceicao.com.br/calendario/junho.asp\#kambô. Acesso em 02 de junho de 2006.

26 O que remete diretamente a uma discussão sobre a "busca das origens" do kambô, até certo ponto num sentido religioso. Novamente de modo bastante próximo dos daimistas, cuja visita ao Céu do Mapiá representa uma certa "peregrinação iniciática" que confere legitimidade e saber ao fardado (Labate 2005).

27 Trata-se de um pseudônimo, o médico solicitou não ser identificado.

28 Não nos é possível saber se estamos aqui tratando da mesma pessoa, mas Lopes (2005) afirma que um médico (não mencionou o nome) que visitou Cruzeiro do Sul para tratar-se com kambô indagou a Genildo (o neto de Francisco Gomes) acerca da eficácia da utilização da rã, perguntando: "se é tão bom, por que seu avô morreu?". A resposta de Genildo explicita a disputa entre médicos e terapeutas, teria ele dito: "se fosse assim, médico também não morria".

29 Trata-se de uma iniciativa do Ministério do Meio Ambiente (MMA) de articular um conjunto de pesquisadores (biólogos moleculares, herpetólogos e antropólogos) para estudar o potencial de exploração comercial do kambô e, ao mesmo tempo, os impactos ambientais e sociambientais de sua difusão. Para maiores detalhes sobre a iniciativa do MMA e sobre as expectativas que os Katukina nutrem em relação a tal projeto, ver Martins (2006).

30 Embora em outro contexto, essa concepção de que brancos elaboram documentos e os índios simplesmente assinam aparece em outras partes do Brasil. As coisas se passam aqui de modo bastante próximo ao que descreveu Ávila (2005) sobre os Krahô, com a diferença significativa de que os Krahô se opuseram à atuação de cientistas, e não de terapeutas. As lideranças katukina parecem ter optado, na ocasião, em romper com os terapeutas porque esperavam estabelecer acordos e contratos com os cientistas do "Projeto Kampô", coordenado pelo Ministério do Meio Ambiente (ver nota 29).

31 A mesma terapeuta acrescentou que "os índios não contam tudo para vocês (antropólogos)" e continuou: "vocês acham que entendem eles, mas não conhecem eles de verdade" explicitando a existência de uma disputa dos terapeutas urbanos com os antropólogos. 


\section{REFERÊNCIAS BIBLIOGRÁFICAS}

ÁVILA, Tiago. 2005. “Não é do Jeito que Eles Quer, é do Jeito que Nós Quer": biotecnologia e o acesso aos conhecimentos tradicionais dos Krahô. Dissertação de Mestrado. Brasília: Universidade de Brasília.

BECKER, Howard S. 1966. Outsiders: studies in the sociology of deviance. Londres: Free Press of Glencoe.

CARNEIRO, Robert. 1970. "Hunting and Hunting Magic among the Amahuaca of the Peruvian Montaña”. Ethnology 9(4): 331-341.

CARNEIRO, Henrique. 2002. Amores e Sonhos da Flora. Afrodisíacos e alucinógenos na botânica e na farmácia. São Paulo: Xamã.

. 2005. “Transformações do Significado da Palavra 'Droga': das especiarias coloniais ao proibicionismo contemporâneo". In: Renato P. Venâncio e Henrique S. Carneiro (orgs.) Álcool e Drogas na História do Brasil. Belo Horizonte/São Paulo: Editora da PUC-Minas/Alameda.

2005. Pequena Enciclopédia da História das Drogas e Bebidas. Rio de Janeiro: Campus/Elsevier.

. (no prelo). "Autonomia ou Heteronomia nos Estados Alterados de Consciência". In Beatriz Labate, Maurício Fiore e Sandra Goulart (orgs) Drogas: perspectivas em ciências humanas. Campinas: Editora Mercado de Letras.

CARNEIRO DA CUNHA, Manuela. 2005. “Des Grenouilles et des Hommes". Télérama hors série, Les Indiens du Brésil. Março 2005, pp. 80-83.

DALY, J. W., J. Caceres, R. W. Moni, F. Gusovsky, M. Moo, K. B. Seamon, K. Milton E C. Myers. 1992. “Frog Secretions and Hunting Magic in the Upper Amazon: identification of a peptide that interacts with an adenosine receptor". Proceedings of the National Academy of Sciences 89: 10960-10963.

DA MATTA, Roberto. 1973. “Panema: uma tentativa de análise estrutural”. In Ensaios de Antropología Estrutural. Petrópolis: Vozes.

DOUGLAS, Mary. 1976. Pureza e Perigo. São Paulo: Perspectiva.

FIORE, Maurício. 2002. "Algumas Reflexões sobre os Discursos Médicos a Respeito do Uso de 'Drogas'". Disponível em http://www.neip.info/downloads/anpocs.pdf.

2004. Controvérsias Médicas e a Questão do Uso de Drogas. Dissertação de Mestrado em Antropologia Social. São Paulo: Universidade de São Paulo.

GINZBURG, Carlo. 1991. História Noturna. Decifrando o Sabá. São Paulo: Companhia das Letras.

LABATE, Beatriz. 2004a. A Reinvenção do Uso da Ayahuasca nos Centros Urbanos. Campinas: Mercado de Letras/ FAPESP.

.2004b. Ayahuasca Mamancuna merci beaucoup: diversificação e internacionalização do vegetalismo ayahuasqueiro peruano. Exame de qualificação do Doutorado em Ciências Sociais. Campinas: Unicamp.

LABATE, Beatriz C. e Wladimyr Sena Araújo (orgs.). 2004. O Uso Ritual da Ayahuasca. 2a ${ }^{\text {a }}$ ed. Campinas: Mercado de Letras/FAPESP. 
LABATE, Beatriz; Sandra Goulart; Henrique Carneiro. 2005. "Introdução". In B. Labate e S. Goulart (orgs.) O Uso Ritual das Plantas de Poder. Campinas: Mercado de Letras/FAPESP.

LIMA, Edilene Coffaci de. 2000. Com a Pedra da Serpente. Homens, animais e espíritos nas concepções Katukina sobre a natureza. Tese de doutorado. São Paulo: Universidade de São Paulo/ Departamento de Antropologia.

. 2005. “Kampu, kampo, kambô: o uso do sapo-verde entre os Katukina”. Revista do IPHAN 32: 254-267.

LIMA, Edilene C. e Beatriz C. Labate. 2006. "Das Florestas Acreanas aos Grandes Centros Urbanos". In Carlos A. Ricardo e Fany Ricardo (orgs) Povos Indígenas no Brasil: 2001/2005. São Paulo: Instituto Socioambiental.

. (no prelo). "A Expansão Urbana do Kambô (Phyllomedusa bicolor): notas etnográficas". In B. Labate, M. Fiore e S. Goulart (orgs) Drogas: perspectivas em ciências humanas. Campinas: Editora Mercado de Letras.

LOPES, Leandro Altheman. 2005. Kambô, a Medicina da Floresta (experiência narrativa). Trabalho de conclusão de curso em Comunicação Social - habilitação Jornalismo e Editoração. São Paulo: Universidade de São Paulo. Disponível em http://www.neip.info/downloads/leandro_kambo.pdf.

MAGNANI, José Guilherme. 1999. “O Xamanismo Urbano e a Religiosidade Contemporânea”. Religião e Sociedade 20(2): 113-140.

MARTINS, Homero Moro. 2006. Os Katukina e o Kampô: aspectos etnográficos da construção de um projeto de acesso a conhecimentos tradicionais. Dissertação de Mestrado. Brasília: Universidade de Brasília/ Departamento de Antropologia.

MILTON, Katherine. 1994. “No Pain, no Game”. Natural History IX: 44-51.

MORAES, Ricardo Gaiotto. s/d. "Macunaíma: um esboço do Brasil". Publicaçóes de alunos de graduação e pós-graduação do Instituto de Estudos da Linguagem da UNICAMP (Especial Macunaíma). Disponível em http://www.unicamp.br/iel/site/alunos/publicacoes/.

NEGRI, L., G. F. Erspamer, C. Severini, R. L. Potenza, P. Melchiorri E V. Erspamer. 1992. “Dermorphin-related peptides from the skin of Phyllomedusa bicolor and their amidated analogs activate two $\mu$ opioid receptor subtypes that modulate antinociception and catalepsy in the rat". Proceedings of the National Academy of Sciences 89: 7203-7207.

OTT, Jonathan. 2004. "Farmahuasca, Anahuasca e Jurema Preta: farmacologia humana de DMT oral mais harmina". In Beatriz C. Labate e Wladimyr Sena Araújo (orgs.) O Uso Ritual da Ayahuasca. 2a . ed. Campinas: Mercado de Letras/ FAPESP.

PÉREZ GIL, Laura. 1999. Pelos Caminhos de Yuve: conhecimento, cura e poder no xamanismo Yawanawá. Dissertação de Mestrado em Antropologia Social. Florianópolis: Universidade Federal de Santa Catarina.

ROSE, Isabel Santana de. 2005. Espiritualidade, Terapia e Cura: um estudo sobre a expressão da experiência no Santo Daime. Dissertação de Mestrado em Antropologia Social. Florianópolis: Universidade Federal de Santa Catarina.

RUDGLEY, Richard. 1993. Essential Substances. A cultural history of intoxicants in society. Nova York: Kodansha International.

RUDGLEY, Richard. 1999. Enciclopedia de las Substancias Psicoativas. Barcelona: Paidós. pp. 274-280.

SEIBEL, Sergio Dario e Alfredo Toscano Jr. 2000. "Conceitos Básicos e Classificação Geral das Substâncias Psicoativas". In S. D. Seibel e A. Toscano Jr. (orgs). Dependência de Drogas. São Paulo: Atheneu. 
SHEPARD Jr., Glenn. 2005. “Venenos Divinos: plantas psicoativas dos Machiguenga do Peru”. In B. Labate e S. Goulart (orgs.) O Uso Ritual das Plantas de Poder. Campinas: Mercado de Letras.

SOARES, Luiz Eduardo. 1994. O Rigor da Indisciplina. Ensaios de Antropologia Interpretativa. Rio de Janeiro: Iser/RelumeDumará.

SOUZA, Moisés Barbosa et alii. 2002. "Anfíbios". In Manuela Carneiro da Cunha e Mauro Almeida (orgs). Enciclopédia da Floresta. O Alto Juruá: práticas e conhecimentos das populações. São Paulo: Cia. das Letras.

VentuRA, Zuenir. 2003. Chico Mendes. Crime e castigo. São Paulo: Companhia das Letras.

ZINBERG, Norman. 1984. Drug, Set and Setting. Nova Haven: Yale University Press.

\section{Jornais, Revistas e Sítios Eletrônicos}

ANTUNES, Archibaldo. 2001. "A Magia do Kambô". Outras Palavras. Rio Branco, Número 13.

ARANHA, Ana. 2006. “E a Princesa Beijou o Sapo". Época, 23 de janeiro de 2006.

BEZERRA, José Augusto. 2004. "A Ciência do Sapo". Globo Rural n 228. Outubro.

DINIZ, Tatiana. 2005. "Apesar de Proibida, Pacientes Recorrem à Vacina do Sapo". Folha de S. Paulo, 03 de novembro, Caderno Equilíbrio.

GORMAN, Peter. 1993. “Making Magic”. Omni Magazine. Julho. Disponível em http://www.pgorman.com/MakingMagic. htm. Acesso em 21 de novembro de 2005.

. 1995. "Between the Canopy and the Forest Floor". High Times Magazine. Janeiro.

Disponível em http://www.pgorman.com/BetweentheCanopyandtheForestFloor.htm.

Acesso em 21 de novembro de 2005.

LABATE, Bia. 2005. “A Rã que Cura?" Superinteressante. Maio, nº 213.

. “O Pajé que Virou Sapo e Depois Promessa de Remédio Patenteado". Disponível em http://www.antropologia.

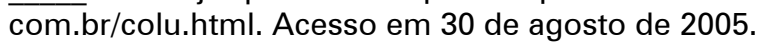

LAGES, Amarílis. 2005. "Uso de Veneno de Rã deixa Floresta e ganha Adeptos nas Metrópoles". Folha de S. Paulo, 12 de abril, página C3.

LOPES, Leandro A. 2001. “Herança da Floresta”. Outras Palavras. Rio Branco, no 13.

PÁGINA 20. “Cura do Câncer”. Rio Branco, 2 de julho de 2003.

PRADA, Paulo. 2005. "Poisonous Tree Frog Could Bring Wealth to Tribe in Brazilian Amazon". New York Times, 30 de maio de 2006.

REUTERS. "Brazilian Frog Could Cure Diseases". 12 de junho de 2006. http://www.reuters.com/news/video/ videoStory?videold=1344 Acesso em 23/02/2007.

WEISS, Bruno. 2006. “Povo Katukina Faz Alerta Contra Uso Indevido do Kampô, a 'Vacina do Sapo'”. Instituto Socioambiental. Disponível em http://www.socioambiental.org/nsa/detalhe?id=2247. Acesso em 27 de abril de 2006. 
“Remédio da Ciência" e "Remédio da Alma": os usos da secreção do kambô (Phyllomedusa bicolor) nas cidades RESUMO

Desde a metade da última década, em grandes cidades do Brasil, começou a se difundir o uso da secreção da rã Phyllomedusa bicolor. Tradicionalmente usada como revigorante e estimulante para caça por grupos indígenas do sudoeste amazônico (entre eles, Katukina, Yawanawá e Kaxinawá), tem havido um duplo interesse pelo kambô nos centros urbanos: como um "remédio da ciência" - no qual se exaltam suas propriedades bioquímicas - e como um "remédio da alma" - onde o que mais se valoriza é sua "origem indígena". A difusão urbana do kambô temse dado, sobretudo, em clínicas de terapias alternativas e no ambiente das religiões ayahuasqueiras brasileiras. Os aplicadores são bastante diversos entre si: índios, ex-seringueiros, terapeutas holísticos e médicos. Neste artigo apresentamos uma etnografia da difusão do kambô, analisando sobretudo o discurso que esses diversos aplicadores têm elaborado sobre o uso da secreção, compreendida por alguns como uma espécie de 'planta de poder', análoga ao peiote e a ayahuasca.

PALAVRAS-CHAVE: kambô, katukina, terapias alternativas, religiões ayahuasqueiras, Nova Era.

\section{"Remedy of Science" and "Remedy of Spirit": the urban uses of the secretion of kambô (Phyllomedusa bicolor)}

\section{ABSTRACT}

Since the second half of the last century, large cities in Brazil began to see the diffusion of the use of a secretion from the frog Phyllomedusa bicolor. Traditionally used as a stimulant and an invigorating agent for hunting by indigenous groups in the southeast of the Amazon (such as the Katukina, Yawanawá and the Kaxinawá), kambô has found a double interest in urban centers: as a "remedy of science", in which biochemical properties are stressed, and as a "remedy of spirit", in which the "indigenous origins" are more valued. The urban diffusion of the use of kambô has mainly taken place via healing clinics which offer alternative therapies and via the Brazilian ayahuasca religions. Kambô providers are quite diverse, including indigenous healers, ex-rubber tapers, holistic therapists and doctors. In this article we present an ethnography of the diffusion of the use of kambô. The analysis focuses mostly on the discourses that various providers have developed around the use of this secretion, believed by some to be a kind of 'power plant' analogous to peyote and ayahuasca.

KEYWORDS: Kambô, katukina, alternative therapies, ayahuasca religions, New Age.

Recebido em 13/03/2007

Aprovado em 11/07/2007 